\section{Colours of Jupiter}

IN an interesting speculation, Wildt ${ }^{1}$ suggested that the red and blue colours observed on Jupiter may be due to combinations of the alkali or alkaline earth metals with the ammonia which forms a large part of its atmosphere: the red to concentrated or 'metallie' solutions, the blue to dilute solutions. He left open the question of the source of the metals, but favoured the idea of meteoric dust, because of the spectroscopic detection of sodium in the night sky.

Although ingenious, the theory is improbable on several grounds. Even in the complete absence of oxygen and water it does not appear that the considerable quantities of metal required could be accumulated over the necessarily long period of time (the 'metallic' phase is $7 N$ with regard to sodium at $-110^{\circ}$ ), since it is known that light ${ }^{2}$, and traces of transition metals, especially iron ${ }^{3}$, which occur in meteoric dust, eatalyse reaction with ammonia to give the colourless metal amides. Also, the red colours have been described as varying from 'brickred' to 'rose-pink', while the 'metallic' phase of sodium in ammonia has a lustre of polished bronze, and solid calcium hexammine resembles brass ; both are blue by transmitted light in thin layers. It is most unlikely, therefore, that they can give rise to true red colours either in solid, liquid or dispersed states.

The blue colour of metals in ammonia (visible at concentrations of less than $0.00002 N$ even with small volumes) is due to solvated electrons ${ }^{4}$ and may be observed in solutions of ammonium $\left(\mathrm{NH}_{4}+, e^{-}\right)$, so that a process for generating electrons (or ammonium radicals) may give rise to such a colour. On Jupiter possible sources of these may be found in photochemical reactions or atmospheric electrical charges.

\section{Dyson Perrins Laboratory, University, Oxford. Feb. 5 .}

Arthur J. Brrch

${ }^{1}$ Wildt, R., Mon. Not. Roy. Ast. Soc., 99, 616 (1938).

Ogg, R. A., Leighton, P. A., and Bergstrom, F. W., J. Amer. Chem. Soc., 55, 1754 (1933). Saughan, T. H., Vogt, R. R., and Nieuwland, J. A., J. Amer. Chem.
Soc., 56, 2120 (1934).

‘Fernelius, W. C., and Watt, G. W., Chem. Rev., 20, 195 (1937).

\section{The Desert Landscape}

Writr arable land one of the most outstanding problems of the day, it is important to determine the criteria of the desert landscape so that reconstruction through the soil can be planned and commenced on a world scale ${ }^{1}$. Various definitions have been given of the nature of a desert, mostly based on weather (although the writers really mean climate), such as lack of rainfall or high rate of evaporation.

All such definitions become unwieldy and unworkable when applied in practice. For example, there is no lack of deserts which have high rainfalls, up to $60 \mathrm{in}$. per annum. Others have 20 in. and are still barren. It is difficult to formulate desert criteria unless the problem is approached from the soil point of view. If we define the desert landscape as one where the rate of soil erosion exceeds the rate of soil formation, and a genial area as one where the rate of soil formation is commensurate with erosion, then at once we have a dynamic conception which the soil conserva- tionist ean apply with vigour to his problems. This definition has the advantage that deserts are more likely to occur in areas where the equilibrium between rainfall and rate of evaporation is unstable, and hence deserts may form easily by soil erosion, without requiring changes of climate. This applies to South Africa, and many workers have shown the desert invasion that is now taking place without any change in climate that can be detected. Dr. Tidmarsh in the Karroo has prepared maps showing the increased desiccation of the soil that has taken place in the span of a few generations. With my colleagues I have drawn maps showing the present invasion, and others of the Pleistocene, Pliocene and Miocene are now being completed ${ }^{2}$.

It is interesting to compare Pole-Evans' vegetation map with the rainfall distribution map of South Africa. There is general agreement, it is true, but very serious discrepancies in the central regions where desert vegetation is shown in rainfall areas of $20 \mathrm{in}$. per annum or more. When Pole-Evans' map is compared with that compiled by my colleagues and $\mathrm{I}$, there is seen to be very close agreement indeed. In our map, as now brought up to date, the similarity is very close. When it is borne in mind that the maps were based on different criteria (in our map, on the sheet erosion that occurs in an area), then it is realized that this experimental approach has real merit.

$$
\begin{gathered}
\text { P.O. Olifantsfontein, } \\
\text { Transvaal. } \\
\text { Jan. } 26 .
\end{gathered}
$$
2 Wrench, G. T., "Reconstruction by Way of the Soil" (Faber and
Faber, 1946). " Bosazza, V. L., Adie, R. J., and Brenner, S., "Man and the Great
Kalahari Desert", Natal Univ. Coll. Sci. Soc., 5, 9 (1946).

\section{Action of Mustard Gas ( $\beta \beta^{\prime}$-Dichlorethylsul- phide) on Thiol Groups of Proteins}

IN order to avoid any mistaken interpretation of the facts published in various papers ${ }^{1}$, we wish to state clearly that the $\beta \beta^{\prime}$-dichlorethylsulphide we used in our investigations was a very pure colourless liquid of constant melting point prepared from constant-boiling thiodiglycol by the action of hydrochloric acid. It is known that impure mustard gas reacts more readily with-SH groups than the pure substanc $\theta^{2}$. It appeared from the discussion at the recent Congrès de Chimie Biologique (Liège, October 1946), following the presentation of a paper by Prof. R. A. Peters, that our conclusions about the action of the various war toxic gases are generally in close agreement with those of the British and American authors (see ref. 3).

Laboratories of General Pathology

Z. M. BACQ

V. Desreux

M. GOFFART and Physical Chemistry, University, Liège.

${ }^{1}$ Bacq, Z. M., Goffart, M., and Angenot, P., Bull. Acad. Roy. Med. Belg., 255 (1940). Bacq, Z. M., and Desreux, V., Acta Biol. Belg., 2, 369 (1942). Bacq, Z. M., Bull. Acad. Roy. Med. Belg., 500
(1942), and also in the press. Bacq, Z. M., and Fischer, P.,Bull. (1942), and also in the press. Bacq, Z. M., and Fischer, P., Bull. Soc. Chim. Biol., 28, 234 (1946). Bacq, Z. M., Experientia, 2, 349 the press.

${ }^{2}$ Herriott, R. M., Anson, M. L., and Northrop, J. H., J. Gen. Physiol., 30, 185 (1946).

${ }^{3}$ Bacq, Z; M., “Travaux Récents sur les Toxiques de Guerre: Le BAL", Actualités Biochimiques (Desoer, Lidge, 1947). 